\title{
METODE EKSTRAKSI DNA CABAI (Capsicum annuUm L.) MENGGUNAKAN MODIFIKASI BUFER CTAB (CETHYL TRIMETHYL AMMONIUM BROMIDE) TANPA NITROGEN CAIR
}

\author{
Kristianto Nugroho, Rerenstradika T TERryana, Puji Lestari
}

\author{
Balai Besar Penelitian dan Pengembangan Bioteknologi dan Sumberdaya Genetik Pertanian - Badan Litbang Pertanian
} Jalan Tentara Pelajar 3A, Bogor 16111, Telp. 0251-8337975; Faks. 0251-8338820

\section{A B S T RA C T}

Chili pepper is an agricultural commodity having high economic value. The production and supply of chili pepper frequently did not match the increased demand; it caused the market price fluctuated. It is important to create new varieties of chili pepper with high production trait to overcome the scarcity. Therefore the plant breeding activities for chili pepper should be done intensively in both conventional and molecular-based to obtain varieties of chili pepper with expected qualities. In molecular breeding, DNA extraction is the crucial steps of the process. If extracted DNA has an excellent quality and quantity, the next processes normally could be completed with the high-quality result. To date, most methods of DNA extraction used liquid nitrogen to destroy the tough carbohydrates of plant tissue. Liquid nitrogen is nitrogen gas in a fluid state which quite difficult to be distributed to the remote laboratory wit no available storage facility. This study aimed to obtain a modified DNA extraction method, in particular for chili pepper, which capable to produce DNA with high quality and quantity without using liquid nitrogen. The sample used consisted of eight F2 plants including their hybrid-parental of the Kencana and the 0207. This research applied modified Doyle and Doyle method for extraction. Modification of extraction buffer is done through the addition of the $1 \%$ $(\mathrm{w} / \mathrm{v})$ PVP (Polyvinylpyrrolidone) and $0.2 \%$ (v/v) $\beta$-mercaptoethanol. The results showed that the DNA extracted using this method has good quality and quantity, capable of being amplified by using SSR (Simple Sequence Repeat) primer and could be digested by restriction enzyme EcoRI. Besides, this method can reduce dependence on the use of liquid nitrogen, in particular for remote laboratories with no available storage facility.

Key Words: chili pepper (Capsicum annuum L.), DNA extraction, CTAB, liquid nitrogen.

Penulis korespondensi: KRISTIANTO NUGROHO | email: nugrohoxkristianto@gmail.com Dikirim: 20-02-2017 | Diterima: 13-06-2017

\section{PENDAH UL UAN}

Cabai (Capsicum annuum L.) merupakan salah satu tanaman hortikultura yang memiliki nilai ekonomi tinggi. Meningkatnya angka permintaan cabai seringkali tidak diimbangi dengan ketersediaan produk, sehingga membuat harga cabai cenderung fluktuatif di pasaran (Irawan, 2007). Salah satu cara untuk meningkatkan produksi cabai adalah melalui perakitan varietas unggul baru (Syukur et al., 2010). Oleh karena itu kegiatan pemuliaan tanaman cabai perlu dilakukan secara intensif baik secara konvensional maupun berbasis molekuler untuk memperoleh varietas unggul cabai dengan sifat sesuai dengan yang diharapkan.

Dalam kegiatan pemuliaan berbasis molekuler, ekstraksi DNA merupakan tahap yang sangat penting dan menentukan tahapan selanjutnya (Fulton et al., 1995). Diperlukan DNA dengan kualitas dan kuantitas yang memadai untuk kegiatan berbasis molekuler seperti Polymerase Chain Reaction (PCR), Southern blotting, konstruksi pustaka genomik, hingga sekuensing (Ibrahim, 2010). Kehadiran senyawa kontaminan seperti polisakarida dan polifenolyang ikut terekstraksi seringkali menghambat kerja enzim tertentu sehingga harus dihindari (Hoarau et al., 2007). Oleh karena itu dibutuhkan metode ekstraksi yang mampu menghasilkan DNA dengan kuantitas dan kualitas yang baik.

Cabai merupakan salah satu tanaman yang memiliki kandungan polisakarida pada daun cukup tinggi (Prince et al., 1997) dan lokasi penanamannya yang cukup jauh dari kota seringkali membuat sampel daun tanaman ini terdegradasi selama perjalanan (Ogunkanmi et al., 2008). Selama ini metode ekstraksi DNA yang dikembangkan umumnya menggunakan nitrogen cair untuk menghancurkan dinding sel tanaman dan menonaktifkan komponen kimiawi sel tertentu (Sharma et al., 2010). Kelemahan penggunaan nitrogen cair akan muncul bila lokasi penelitian jauh dari kota sehingga nitrogen cair sulit diperoleh (Dhakshanamoorthy and Selvaraj, 2009). Selain itu menurut Ahmed et al. (2009) nitrogen cair merupakan komponen yang tidak aman sehingga memerlukan penyimpanan khusus. Tujuan penelitian ini adalah untuk memperoleh metode ekstraksi DNA cabai yang memiliki kuantitas dan kualitas yang baik melalui modifikasi bufer ekstraksi tanpa menggunakan nitrogen cair.

\section{MET ODE}

Materi Genetik. Bahan tanaman yang digunakan terdiri atas sepuluh genotipe cabai yang terdiri atas delapan tanaman F2 hasil persilangan antara varietas Kencana dengan galur 0207, beserta kedua tetua tersebut yang ditanam di kebun percobaan Balitsa di Lembang, Jawa Barat. Bagian yang diambil berupa daun dari tanaman yang telah berumur sekitar 8 bulan. Sampel daun dipanen pada bulan Januari 2016 dan telah mengalami penyimpanan di lemari pendingin bersuhu $-50^{\circ} \mathrm{C}$ selama hampir enam bulan.

Bufer Ekstraksi. Ekstraksi DNA dilakukan dengan menggunakan metode Doyle \& Doyle (1990) yang dimodifikasi. Modifikasi dilakukan melalui penambahan senyawa PVP (Polyvinylpyrrolidone) dan $\beta$-merkaptoetanol. Bahan-bahan untuk pembuatan bufer ekstraksi terdiri atas $2 \%(\mathrm{w} / \mathrm{v}$ ) CTAB (Cetyl trimethylammonium bromide), 100 
mM Tris-HCl pH 8.0, 1.4 M NaCl, 20 mM EDTA pH 8.0, dan 1\% $(\mathrm{w} / \mathrm{v})$ PVP. Senyawa PVP baru ditambahkan ke dalam bufer saat kegiatan ekstraksi akan dilakukan, sementara senyawa $\beta$-merkaptoetanol tidak dicampurkan ke dalam bufer ekstraksi secara langsung namun ditambahkan sendiri karena sifatnya yang berbahaya dan baunya yang menyengat. Bufer ekstraksi dipanaskan terlebih dahulu pada suhu $60^{\circ} \mathrm{C}$ sambil distirer untuk memudahkan homogenasi komponen, kemudian didinginkan di es selama 10 menit sebelum digunakan.

Metode Ekstraksi. Sebanyak $200 \mathrm{mg}$ daun cabai dimasukkan ke dalam tabung Eppendorf $2 \mathrm{ml}$ yang telah diautoklaf. Selanjutnya dilakukan penambahan bufer ekstraksi yang telah didinginkan sebanyak $200 \mu \mathrm{l}$ lalu sampel digerus dengan alat blue pestle hingga lumat. Selanjutnya bufer ekstraksi ditambahkan kembali ke dalam sampel tersebut hingga volumenya tepat menjadi $1 \mathrm{ml}$. Sampel yang telah digerus lalu disimpan dalam es sambil menunggu sampel-sampel lainnya selesai digerus. Selanjutnya dilakukan penambahan RNAse A $(10 \mathrm{mg} / \mathrm{ml})$ sebanyak $5 \mu \mathrm{l}$ pada tiap sampel. Sampel kemudian dibolak-balik hingga tercampur merata lalu diinkubasi pada suhu $37^{\circ} \mathrm{C}$ selama 10 menit. Selanjutnya dilakukan penambahan $\beta$-merkaptoetanol sebanyak $2 \mu \mathrm{l} /$ sampel, kemudian dibolak-balik hingga tercampur merata.

Sampel kemudian diinkubasi pada suhu $65^{\circ} \mathrm{C}$ di dalam water bath (ThermoScientific, USA) selama 30 menit dan dihomogenkan dengan cara dibolak-balik setiap 10 menit. Setelah diinkubasi sampel didinginkan terlebih dahulu pada suhu ruang selama 3 menit, diikuti penambahan larutan fenol : kloroform (1: 1) ke dalam tiap sampel sebanyak 1 kali volume buffer ekstraksi. Campuran lalu dihomogenkan dengan cara dibolak-balik selama 3 menit hingga merata. Setelah itu campuran disentrifugasi pada kecepatan 12.000 rpm selama 10 menit pada suhu $25^{\circ} \mathrm{C}$. Supernatan yang terbentuk lalu dipindahkan ke tabung Eppendorf baru. Selanjutnya dilakukan penambahan larutan kloroform sebanyak 1 kali volume supernatan. Campuran lalu disentrifugasi kembali pada kecepatan $12.000 \mathrm{rpm}$ selama 10 menit pada suhu $25^{\circ} \mathrm{C}$. Supernatan yang terbentuk lalu dipindahkan ke tabung Eppendorf baru. Selanjutnya dilakukan penambahan natrium asetat $3 \mathrm{M}$ pH 5.2 sebanyak $1 / 10$ kali volume supernatan diikuti penambahan isopropanol sebanyak satu kali volume supernatan. Campuran kemudian dibolak-balik secara perlahan lalu didiamkan pada suhu ruang selama 15 menit.

Campuran lalu disentrifugasi dengan kecepatan 12.000 rpm selama 10 menit pada suhu $25^{\circ} \mathrm{C}$. Supernatan kemudian dibuang dan pelet DNA yang terbentuk lalu dicuci dengan larutan $70 \%$ etanol sebanyak $500 \mu$ l. Selanjutnya dilakukan sentrifugasi selama 5 menit pada kecepatan $12.000 \mathrm{rpm}$ suhu $25^{\circ} \mathrm{C}$. Supernatan kemudian dibuang dan pelet yang terbentuk kemudian dikeringanginkan untuk menghilangkan sisa-sisa etanol. Pelet yang telah kering lalu dilarutkan dalam $100 \mu$ larutan TE $(10 \mathrm{mM}$ Tris $\mathrm{pH} 8.0$ dan 1 mM EDTA) dan larutan DNA stok kemudian disimpan pada suhu $-20^{\circ} \mathrm{C}$ hingga siap digunakan.

Uji Kuantitatif dan Kualitatif DNA Cabai. Larutan DNA stok cabai yang diperoleh dari hasil ekstraksi lalu diuji secara kuantitatif dan kualitatif. Uji kuantitatif dilakukan menggunakan alat berupa NanoDrop Spektrofotometer (ThermoScientific, USA) sedangkan uji kualitatif dilakukan dengan teknik elektroforesis pada gel agarose $1 \%$ pada tangki berisi buffer $1 \mathrm{x}$ TAE (Tris-Acetate-EDTA), dengan tegangan 90 volt selama 30 menit. Hasil elektroforesis kemudian diamati di dalam alat UV TransIlluminator (UVP, UK).
Amplifikasi DNA. Tiap sampel diamplifikasi dalam total reaksi $10 \mu \mathrm{l}$ mengandung $10 \mathrm{ng}$ DNA template sebanyak $1 \mu \mathrm{l}$; KAPA 2G FastReadyMix (KapaBiosystems, USA) sebanyak 5 $\mu \mathrm{l}$; primer Forward dan Reverse dengan konsentrasi $10 \mu \mathrm{M}$ masing-masing sebanyak $0.5 \mu \mathrm{l}$, dan $\mathrm{ddH}_{2} \mathrm{O}$ steril. Amplifikasi dilakukan dengan menggunakan dua pasang primer SSR yaitu CaSSRBio 6.2 dan CaSSRBio 10.2 yang didisain berbasis genom cabai. Urutan sikuen forward primer CaSSRBio 6.2 adalah 5'-TGAGAGGTTGAAGAGAAATTGA-3' urutan sikuen reverse adalah 5'-CTTCTTCTCCTTTTTCGTCTT-3'. Sedangkan urutan sikuen forward primer CaSSRBio 10.2 adalah 5'ACGAACAAGAAAAACACGATA-3' sedangkan urutan sikuen reverse adalah 5'-CATTATACTCGCCTGTCACTT-3'.

Reaksi PCR dilakukan dalam mesin PCR T1 Thermocycler (Biometra, Germany) dengan profil PCR sebagai berikut: denaturasi awal dilakukan pada suhu $95^{\circ} \mathrm{C}$ selama 3 menit, diikuti oleh sebanyak 35 siklus proses denaturasi pada suhu $95^{\circ} \mathrm{C}$ selama 15 detik, annealing (tahap penempelan primer) pada suhu $55^{\circ} \mathrm{C}$ selama 15 detik, dan elongation (tahap perpanjangan basa) pada suhu $72{ }^{\circ} \mathrm{C}$ selama 15 detik. Reaksi PCR diakhiri dengan siklus final extension (tahap akhir perpanjangan basa) pada suhu $72^{\circ} \mathrm{C}$ selama 1 menit. Hasil PCR kemudian dielektroforesis pada gel agarose $1 \%$ pada tangki berisi buffer $1 \mathrm{x}$ TAE, dengan tegangan 90 volt selama 35 menit.

Pemotongan DNA dengan Enzim Restriksi. Kemampuan DNA cabai hasil ekstraksi untuk digunakan dalam teknik hibridisasi diuji dengan menggunakan enzim restriksi. Reaksi pemotongan dilakukan dengan mereaksikan $1 \mu \mathrm{g}$ DNA dengan $2 \mu \mathrm{l}$ 10x buffer enzim restriksi (NEB, UK) dan $1 \mu \mathrm{l}$ enzim EcoRI (20.000 U/ml)(NEB, UK) dengan total reaksi 20 $\mu$ l. Sampel kemudian diinkubasi pada suhu $37^{\circ} \mathrm{C}$ selama 6,5 jam. Hasil pemotongan kemudian dielektroforesis pada gel agarose $1 \%$.

\section{HASIL DAN PEMBAHASAN}

Prinsip dasar ekstraksi DNA adalah menghancurkan dinding dan membran sel tanaman lalu mengeluarkan DNA yang terdapat dalam nukleus tanpa menyebabkan kerusakan pada DNA tersebut (Sharma et al. 2010). Sementara menurut Chi et al. (2009), secara umum proses ekstraksi DNA dibagi menjadi beberapa tahap yaitu persiapan materi yang akan digunakan, proses penghancuran sel, penghilangan senyawa kontaminan, dan pengumpulan DNA. Menurut Ogunkanmi et al. (2011) DNA yang diekstrak harus terbebas dari senyawa kontaminan seperti polisakarida, polifenol, dan tanin yang seringkali ikut terbawa dan dapat menghambat kerja beberapa enzim dalam kegiatan molekuler.

Pada penelitian ini terdapat beberapa modifikasi dari metode CTAB yang dikembangkan oleh Doyle \& Doyle (1990). Modifikasi tersebut antara lain berupa penambahan senyawa PVP dan $\beta$-merkaptoetanol pada bufer ekstraksi. Menurut Bintang (2010) CTAB merupakan detejen kationik yang bersifat menghancurkan sel, mengurai protein, dan memisahkan karbohidrat dari asam nukleat. Menurut Li et al. (2011) selama proses penghancuran jaringan, senyawa polifenol yang berasal dari vakuola akan teroksidasi dan berikatan secara kovalen dengan protein dan asam nukleat, menghasilkan warna coklat pada larutan DNA yang diekstraksi. Oleh karena itu senyawa antioksidan seperti PVP, $\beta$-merkaptoetanol, 
Bovine Serum Albumin, dan sodium azida sering ditambahkan untuk menghambat proses oksidasi dan mengurangi timbulnya warna coklat pada DNA (Zidani et al., 2005).

Menurut Križman et al. (2006) senyawa PVP akan berikatan dengan polifenol dan mencegahnya berikatan dengan DNA. Sementara itu senyawa $\beta$ merkaptoetanol selain berperan sebagai antioksidan juga berperan dalam mendegradasi protein (Varma et al. 2007). Senyawa tersebut akan membantu mengurai ikatan sulfat pada struktur protein sehingga protein dapat dieliminasi dengan mudah (Mornkham et al. 2012). Efektivitas penggunaan senyawa PVP dan $\beta$ merkaptoetanol telah dilaporkan antara lain pada proses ekstraksi DNA kunyit dan jahe (Syamkumar et al. 2003); suweg, singkong, ubi jalar, dan talas (Sharma et al. 2008), serta pisang (Shankar et al. 2011).

Selain menggunakan $\beta$-merkaptoetanol proses eliminasi protein juga dilakukan melalui penambahan pelarut organik fenol atau kloroform (Zidani et al., 2015). Menurut Bintang (2010), pelarut tersebut berfungsi menggumpalkan protein yang setelah disentrifugasi akan akan mengendap di fase antara, sementara DNA berada pada fase air di lapisan atas. Selanjutnya DNA yang berada di fase air (supernatan) dan telah terbebas dari protein lalu dipindahkan pada tabung baru dan diberi garam natrium asetat. Menurut Varma et al. (2007) penambahan garam dengan konsentrasi tinggi akan meningkatan kelarutan senyawa polisakarida pada alkohol sehingga polisakarida tidak akan mengendap bersama DNA saat disentrifugasi. Selain natrium asetat, garam lain yang biasa digunakan pada proses ekstraksi DNA adalah $\mathrm{NaCl}$ (Fang et al. 1992; Lodhi et al. 1994) dan ammonium asetat (Möller et al. 1992; Singh \& Kumar 2012).

Tabel 1. Hasil Uji Kuantitatif DNA Cabai dengan Alat NanoDrop Spektrofotometer

\begin{tabular}{rlcc}
\hline No. & Sampel & Konsentrasi DNA (ng/ $\boldsymbol{\mu l})$ & $\mathbf{A}_{\mathbf{2 6 0}} / \mathbf{A}_{\mathbf{2 8 0}}$ \\
\hline 1. & Kencana & 669,6 & 2,4 \\
2. & 0207 & $1.336,9$ & 2,2 \\
3. & F2 No. 19 & 498,7 & 2,2 \\
4. & F2 No. 30 & 378,7 & 2,4 \\
5. & F2 No. 44 & 531,4 & 2,2 \\
6. & F2 No. 53 & 227,0 & 2,2 \\
7. & F2 No. 71 & 529,3 & 2,3 \\
8. & F2 No. 83 & 751,3 & 2,2 \\
9. & F2 No. 131 & 231,0 & 2,7 \\
10. & F2 No. 135 & 293,7 & 2,1 \\
\hline
\end{tabular}

Hasil uji kuantitatif dengan alat Nanodrop Spektrofotometer menunjukkan bahwa DNA cabai yang diekstraksi pada penelitian ini memiliki kisaran konsentrasi dari 227 ng/ $\mu$ lpada sampel F2 No. 53 hingga 1.336,9 ng/ $\mu$ l pada sampel 0207 (Tabel 1). Secara umum konsentrasi DNA yang diperoleh pada metode ini telah mencukupi untuk digunakan dalam kegiatan PCR. Menurut rekomendasi KapaBiosystems (2014) konsentrasi DNA templateyang dibutuhkan untuk kegiatan PCR berkisar antara 10-100 ng/ $\mu \mathrm{l}$.
Hasil pengukuran Nanodrop menunjukkan bahwa nilai perbandingan $\mathrm{A}_{260} / \mathrm{A}_{280}$ sampel cabai pada penelitian ini berkisar dari 2.1 hingga 2.7 (Tabel 1). Menurut Healey et al. (2014) untuk kegiatan molekuler berbasis NGS (Next Generation Sequencing) dibutuhkan DNA dengan perbandingan A260/A280antara 1,8-2,0. DNA yang memiliki nilai perbandingan $A_{260} / A_{280}$ kurang dari 1.8 menunjukkan adanya kontaminan fenol atau senyawa lain yang ikut terbawa selama proses ekstraksi berlangsung sedangkan DNA yang memiliki nilai perbandinganlebih 2.0 tidak menunjukkan adanya kontaminan yang terbawa (ThermoScientific, 2011).

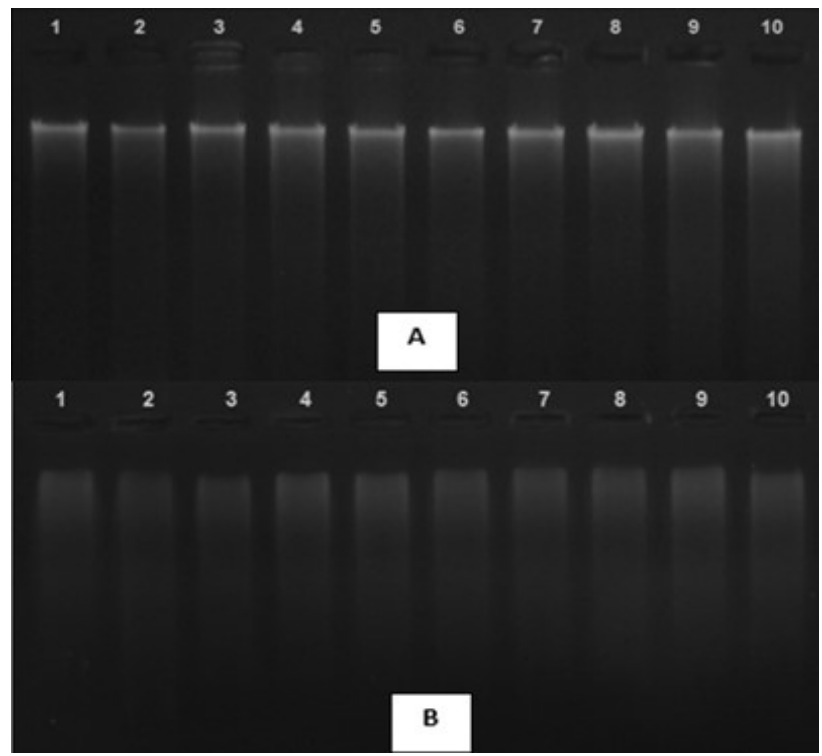

Gambar 1. (A). Hasil Ekstraksi DNA Genomik Cabai pada gel Agarose 1\%, (B). Hasil pemotongan DNA cabai dengan enzim EcoRI pada gel Agarose 1\% . Urutan sampel seperti tercantum pada Tabel 1 .

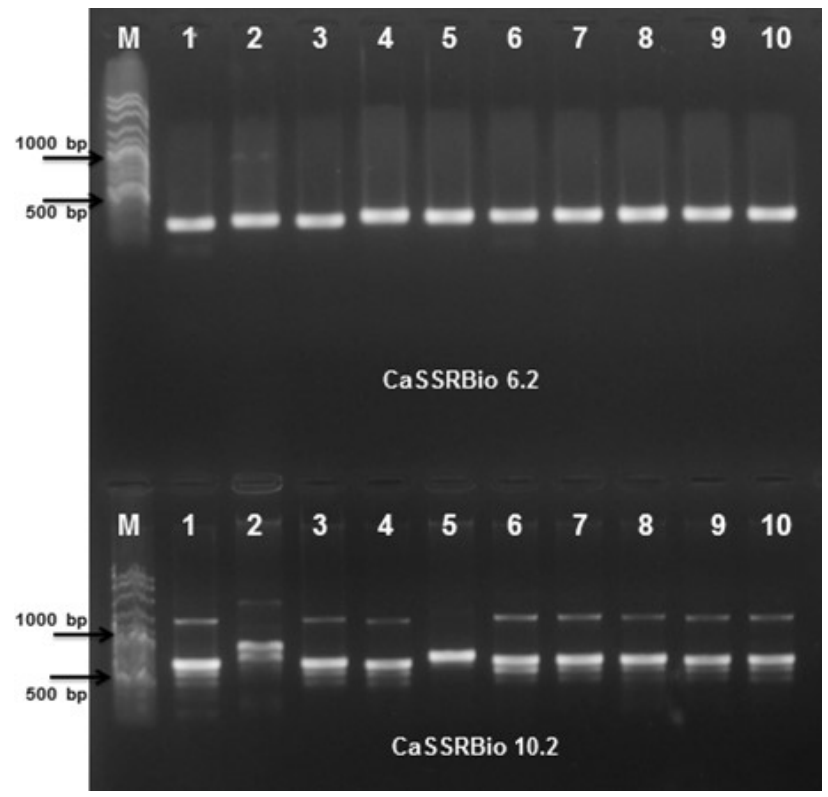

Gambar 2. Hasil Amplifikasi DNA Cabai dengan Primer CaSSRbio 6.2 dan CaSSRBio 10.2 pada Gel Agarose $1 \%$. Keterangan: M: DNA Ladder $100 \mathrm{bp}$. Urutan sampel seperti tercantum pada Tabel 1. 
Sementara itu hasil uji kualitatif dengan menggunakan gel agarose 1\% menunjukkan bahwa kualitas DNA yang diekstraksi dengan metode ini cukup baik. Pita DNA dapat terlihat dengan jelas tanpa adanya degradasi (smear) (Gambar 1). Selain itu DNA cabai yang diekstraksi dengan metode ini juga mampu terpotong dengan baik oleh enzim EcoRI (Gambar 1) dan dapat teramplifikasi dengan baik menggunakan primer SSR (Gambar 2). Tingginya kualitas DNA yang dihasilkan tidak terlepas dari penggunaan bufer ekstraksi yang didinginkan terlebih dahulu sebelum digunakan. Menurut Sahu et al. (2012) semakin rendah suhu yang digunakan pada proses penghancuran jaringan tanaman akan memperkecil peluang terjadinya degradasi DNA. Hasil serupa juga dilaporkan oleh Yingand Zaman (2006) pada penelitian mengenai metode ekstraksi DNA kelapa sawit dari daun yang sudah dewasa di mana penggunaan bufer ekstraksi yang didinginkan terlebih dahulu mampu menghasilkan DNA dengan kualitas yang baik.

\section{K E S I M P U L A N}

Modifikasi bufer ekstraksi pada penelitian ini mampu menghasilkan DNA cabai dengan kuantitas dan kualitas yang baik. DNA yang dihasilkan memiliki kuantitas yang cukup untuk digunakan dalam kegiatan berbasis molekuler seperti PCR. DNA yang dihasilkan juga memiliki pita yang dapat tervisualisasi dengan jelas, mampu terpotong dengan enzim EcoRI dan dapat teramplifikasi dengan baik menggunakan primer SSR. Selain itu metode ini dapat mengurangi ketergantungan pada nitrogen cair yang sulit diperoleh laboratorium yang jaraknya jauh dari kota.

\section{DAFT AR REFERENS I}

Ahmed I, Islam M, Arshad W, Mannan A, Ahmad W, Mirza B. 2009. High-quality plant DNA extraction for PCR: an easy approach. J Appl Genet 50(2):105-107.

Bintang M. 2010. Biokimia Teknik Penelitian.Jakarta:Penerbit Erlangga.

Chi MH, Park SY, Lee YH. 2009. A quick and safe method for fungal DNA extraction. Plant Pathol. J. 25(1):108-111.

Dhakshanamoorthy D, Selvaraj R. 2009. Extraction of genomic DNA from Jatropha sp. using modified CTAB method. Rom. J. Biol. Plant. Biol. 54(2):117-125.

Doyle JJ, Doyle JL. 1990. Isolation of plant DNA from fresh tissue. Focus 12:13-15.

Fang G, Hammar S, Grumet R. 1992. A quick and inexpensive method for removing polysaccharides from plant genomic DNA. Biotechniques.13:52-54.

Fulton TM, Chunwongse J, Tanksley SD. 1995. Microprep protocol of extraction DNA from tomato and other herbaceous plants. Plant Molecular Biology Reporter. 13(3):207-209.

Hoarau G, Coyer JA, Stam WT, Olsen JL. 2007. A fast and inexpensive DNA extraction/purification protocol for brown macroalgae. Molecular Ecology Notes 7:191-193.

Healey A, Furtado A, Cooper A, Henry RA. 2014. Protocol: a simple method for extracting next-generation sequencing quality genomic DNA from recalcitrant plant species. Plant Methods $10: 21$.

Ibrahim RIH. 2010. A modified CTAB protocol for DNA extraction from young flower petals of some medicinal plant species. Geneconserve 10(40):165-182.
Irawan B. 2007. Fluktuasi harga, transmisi harga dan marjin pemasaran sayuran dan buah. Analisis Kebijakan Pertanian 5 (4):358-373

Kapa Biosystems. 2014. KAPA2G Fast HotStart PCR Kit Technical Data Sheet [internet]. Kapa Biosystems Inc., Wilmington, MA. [cited 2017 May 12]. Available from:

https://www.kapabiosystems.com/assets/KAPA2G_Fast_HotSt art TDS.pdf.

Križman M, Jakše J, Baričevič D , Javornik B , Prošek M. 2006. Robust CTAB-activated charcoal protocol for plant DNA extraction. Acta agriculturae Slovenica 87(2): 427-433.

Li JT, Yang J, Chen DC, Zhang XL, Tang ZA. 2007. An optimized minipreparation method to obtain high-quality genomic DNA from mature leaves of sunflower. Genet. Mol. Res. 6 (4):1064-1071.

Lodhi MA, Ye GN, Weeden NF, Reisch BI. 1994. A simple and efficient method for DNA extraction from grapevine cultivars, Vitis species and Ampelopsis.Plant Molecular Biology Reporter 12(1):6-13.

Möller EM, Bahnweg G, Sandermann H, Geiger HH. 1992. A simple and efficient protocol for isolation of high molecular weight DNAfrom filamentous fungi, fruit bodies, and infected plant tissues. Nucleic Acids Researchv 20(22):6115-6116.

Mornkham T, Wangsomnuk PP, Wangsomnuk P, Jogloy S, Pattanothai A, Fu YB. 2012. Comparison of five DNA extraction methods for molecular analysis of Jerusalem artichoke (Helianthus tuberosus). Genetics and Molecular Research 11(1):572-581.

Ogunkanmi AL, Oboh B, Onifade B, Ogunjobi AA, Taiwo IA, Ogundipe OT. 2008 An improved method of extracting genomic DNA from preserved tissues of Capsicum annuum for PCR amplification. EurAsia J BioSci 2:115-119.

Prince JP, Zhang Y, Radwanski ER, Kyle EM. 1997. A versatile and high-yielding protocol for the preparation of genomic DNA from Capsicum spp. (Pepper). HortScience 32 (5): 937-939.

Sahu SK, Thangaraj M, Kathiresan K. 2012. DNA extraction protocol for plants with high levels of secondary metabolites and polysaccharides without using liquid nitrogen and phenol. ISRN Molecular Biology 2012: 1-6.

Shankar K, Chavan L, Shinde S, Patil B. 2011. An improved DNA extraction protocol from four in vitro banana cultivars. Asian Journal of Biotechnology 3(1): 84-90.

Sharma K, Mishra AK, Misra RS. 2008. A simple and efficient method for extraction of genomic DNA from tropical tuber crops.Afr. J. Biotechnol 7(8): 1018-1022.

Sharma P, Joshi N, Sharma A. 2010. Isolation of genomic DNA from medicinal plants without liquid nitrogen. Indian J. Exp. Biol. 48:610-614.

Singh V, Kumar V. 2012. An optimized method of DNA isolation from highly mucilage-rich okra (Abelmoschus Esculentus L.) for PCR analysis.Adv. Appl. Sci. Res. 3(3):1809-1813.

Syamkumar S, Lowarence B,Sasikumar, B. 2003.Isolation and Amplification of DNA fromrhizomes of turmeric and ginger. Plant Molecular Biology Reporter. 21:171a-171e.

Syukur M, Sujiprihati S, Yunianti R, Kusumah DA. 2010. Evaluasi daya hasil cabai hibrida dan daya adaptasinya di empat lokasi dalam dua tahun. J.Agron. Indonesia 38(1):43-51.

ThermoScientific. 2011. Assessment of Nucleic Acid Purity, T042Technical BulletinNanoDrop Spectrophotometers [internet]. Thermo Fisher Scientific Waltham, MA [cited 2017 May 12]. Available from http://www.nanodrop.com/Library/T042NanoDrop-Spectrophotometers-Nucleic-Acid-PurityRatios.pdf..

Varma A, Padh H, Shrivastava N. 2007. Plant genomic DNA isolation: an art or a science. Biotechnol. J. 2:386-392.

Ying ST, Zaman FQ. 2006. DNA extraction from mature oil palm leaves. Journal of Oil Palm Research 18:219-224.

Zidani S, Ferchichi A, Chaieb M. 2005. Genomic DNA extraction method from pearl millet (Pennisetum glaucum) leaves. Afr. J. Biotechnol. 4 (8):862-866. 